\title{
Pelatihan penyusunan laporan keuangan UMKM di Kabupaten Kampar
}

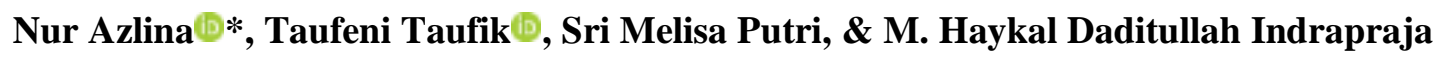 \\ Program Studi Akuntansi, Universitas Riau \\ *nur.azlina@lecturer.unri.ac.id
}

\begin{abstract}
Abstrak. Kegiatan pengabdian masyarakat ini bertujuan untuk 1)memberikan pemahaman tentang akuntansi bagi pengelola UMKM dalam rangka peningkatan kinerja keuangan UMKM, 2) Meningkatkan keterampil menyusun laporan keuangan sesuai SAK EMKM.Metode yang digunakan dalam kegiatan pengabdian pada masyarakat adalah dengan menggunakan metode pelatihan terhadap beberapa penggelola UMKM di Kabupaten Kampar bagi UMKM yang terpilih. Tentang tata cara penyusunan laporan keuangan dengan cara mendatangi satu persatu UMKM yang menjadi sasaran dengan tetap melaksanakan protokol covid-19. Kegiatan Pengabdian dilakukan pada bulan September 2020, yang dimulai pukul 08.00 wib - selesai. Dengan pelatihan ini pengelola UMKM dapat memahami tentang akuntansi dan dapat menyusun laporan keuangan yang sesuai dengan SAK EMKM Indonesia. Dengan adanya laporan keuangan yang disusun sesuai standar akan dapat memberikan informasi keuangan yang lengkap bagi pengelola UMKM, selain itu juga dapat digunakan bagi pengelola sebagai salah satu persyaratan ketika ingin mengajukan pinjaman dana.
\end{abstract}

Kata kunci: laporan keuangan, UMKM, SAK EMKM, Kabupaten Kampar

\begin{abstract}
This community service activity aims to 1) provide an understanding of accounting for MSME managers in order to improve MSME financial performance, 2) Improve skills in compiling financial reports according to SAK EMKM. The method used in community service activities is to use training methods for several MSME managers in Kampar Regency for selected UMKM. Regarding the procedures for preparing financial reports by visiting the target MSMEs one by one while continuing to implement the Covid-19 protocol. Community Service activities are carried out in September 2020, which starts at 08.00 WIB - finished. With this training, MSME managers can understand accounting and can prepare financial reports in accordance with Indonesian SAK EMKM. With the existence of financial reports prepared according to standards, it will be able to provide complete financial information for MSME managers, besides that it can also be used by managers as one of the requirements when they want to apply for a loan.
\end{abstract}

Keywords: financial report, MSMEs, SAK EMKM, Kampar Regency

To cite this article: Azlina, N., T. Taufik., S. M. Putri., \& M. H. D. Indrapraja. 2020. Pelatihan penyusunan laporan keuangan UMKM di Kabupaten Kampar. Unri Conference Series: Community Engagement 2: 66-71. https://doi.org/10.31258/unricsce.2.66-71

(C) 2020 Authors

Peer-review under responsibility of the organizing committee of Seminar Nasional Pemberdayaan Masyarakat 2020 


\section{PENDAHULUAN}

Menurut Undang Undang Nomor 20 Tahun 2008, ciri-ciri UMKM adalah manajemen berdiri sendiri, modal disediakan sendiri, daerah pemasarannya lokal, aset perusahaannya kecil dan jumlah karyawan yang dipekerjakan terbatas. UMKM berperan mempertinggi taraf hidup dan membuka lapangan kerja baru bagi masyarakat pada umumnya (Yuniarta, 2013). Dalam aspek finansial, hanya sedikit UMKM yang mengalami perkembangan dalam hal kinerja keuangannya. Banyak pengelola UMKM tidak bisa menunjukkan dengan nominal angka aset yang mereka miliki. Aset tersebut juga untuk kepentingan pribadi dan tidak terdapat pencatatan ataupun pemisahan di antara keduanya. Secara Umum laporan keuangan berguna untuk mengetahui posisi kekayaan bersih usaha, laba rugi yang diderita selama priode tertentu dan nilai arus kas (uang tunai) yang masuk maupun keluar (Prasetyo, 2010). Pengelolaan keuangan dapat dilakukan melalui akuntansi. Akuntansi adalah proses sistematis untuk mengolah transaksi menjadi informasi keuangan yang bermanfaat bagi para penggunanya (Warsono, 2010).

Penelitian Kurniawati (2012) menunjukkan bahwa kendala yang menghambat UMKM dalam penerapan akuntansi antara lain adalah latar belakang pendidikan, belum pernah mengikuti pelatihan akuntansi dan belum ada kebutuhan terhadap penerapan akuntansi. Hasil penelitian Amani (2018) menunjukkan bahwa Laporan Keuangan belum disusun seperti standar yang ditetapkan Standar Akuntansi keuangan (SAK) Entitas Mikro, Kecil dan Menengah (EMKM). Prajanto dan Septriana (2018), menyatakan bahwa persepsi pengusaha akan laporan keuangan masih sangat rendah sehingga mengakibatkan kualitas laporan keuangan yang dibuat oleh pengusaha UMKM tidak berpengaruh pada besaran kredit yang diperoleh UMKM.

Syahrenny (2019) melakukan pelatihan terhadap pengelola UMKM di Kabupaten Kediri, memberi kesadaran kepada para pengelola UMKM untuk membuat laporan keuangan. Pengabdian lainnya tentang pelatihan akuntansi adalah yang dilakukan oleh Budhi Dharma (2019) pada UMKM didesa Polanharjo, Asih Machfuzhoh (2020) pada UMKM di Kecamatan Grogol, Yumniati Agustina (2019 pada UMKM binaan pusat inkubasi bisnis syariah majelis ulama indonesia, Perwira Pustapa (2019), pada UMKM kota madya Medan. Dari beberapa kegiatan pengabdian ini dapat diketahui bahwa kegiatan pelatihan tentang penyusunan laporan keuangan ini memang sangat diperlukan oleh UMKM, dan disarankan agar dilakukan pelatihan akuntansi untuk UMKM yang lain yang ada di Indonesia.

Ikatan Akuntan Indonesia sudah menyiapkan Standar Akuntansi Keuangan untuk UMKM yang dinamakan dengan SAK-EMKM (Standar Akuntansi Keuangan- Entitas Mikro Kecil dan Menengah) yang resmi diberlakukan efektif 1 Januari 2018. Laporan keuangan entitas menurut Standar Akuntansi Keuangan meliputi; laporan posisi keuangan, laporan laba rugi dan catatan atas laporan keuangan. Akuntansi akan memberikan beberapa manfaat bagi pengelola UMKM, antara lain: (1) UMKM dapat mengetahui kinerja keuangan perusahaan, (2) UMKM dapat mengetahui, memilah, dan membedakan harta perusahaan dan harta pemilik, (3) UMKM dapat mengetahui posisi dana baik sumber maupun penggunaannya, (4) UMKM dapat membuat anggaran yang tepat, (5) UMKM dapat menghitung pajak, dan (6) UMKM dapat mengetahui aliran uang tunai selama periode tertentu. Menurut Mulyaga (2016) dengan membuat laporan keuangan sesuai dengan SAK EMKM ini, pemilik usaha juga dapat membuka kesempatan untuk meminjam modal dari perbankan. Karena salah satu syarat penting untuk mengajukan pinjaman ke bank adalah dengan membuat laporan keuangan.

Berdasarkan hasil penelitian dan survey yang dilakukan oleh tim terhadap kinerja UMKM di Kabupaten Kampar, permasalahan yang dihadapi oleh pengelola UMKM Kabupaten Kampar adalah masih minimnya pengetahuan tentang bagaimana pengelolaan keuangan yang sesuai dengan SAK terutama SAK EMKM, dan rendahnya keinginan untuk menggunakan akuntansi dalam penyusunan laporan keuangan. Kemudian dalam hal penghitungan laba usaha, masih tercampurnya perhitungan pengeluaran pribadi dengan pengeluaran usaha. Hal ini mengakibatkan laporan keuangan yang disusun tidak menggambarkan kondisi usaha yang sebenarnya sehingga belum sesuai dengan SAK EMKM yang berlaku.

Kegiatan pengabdian masyarakat ini bertujuan : 1)memberikan pemahaman tentang akuntansi bagi pengelola UMKM dalam rangka peningkatan kinerja keuangan UMKM, 2) Meningkatkan keterampil menyusun laporan keuangan sesuai SAK EMKM. Khalayak sasaran kegiatan ini adalah UMKM di Kabupaten Kampar. Dipilihnya kelompok sasaran tersebut dengan pertimbangan bahwa pengusaha kecil di Kabupaten Kampar belum memiliki kemampuan yang memadai mengenai cara penyusunan laporan keuangan sesuai SAK EMKM.

Berdasarkan permasalahan tersebut, perlu diadakan kegiatan pelatihan bagi pengelola UMKM yang ada di Kabupaten Kampar tentang penyusunan laporan keuangan UMKM. Dengan adanya kegiatan ini diharapkan 
pengelola UMKM di Kabupaten Kampar dapat menyusun laporan keuangan yang sesuai dengan SAK EMKM sehingga bermanfaat dalam meningkatkan kinerja UMKM.

\section{METODE PENERAPAN}

Metode yang digunakan dalam kegiatan pengabdian pada masyarakat adalah dengan menggunakan metode pelatihan terhadap beberapa UMKM di Kabupaten Kampar tentang tata cara penyusunan laporan keuangan dengan cara mendatangi satu persatu UMKM sasaran dengan protokoler covid19 lengkap.Melalui pelatihan tersebut diharapkan peserta dapat melakukan penyusunan laporan keuangan yang sesuai dengan SAK EMKM. Adapun tahapan pelaksanaan kegiatan tersebut adalah sebagai berikut:

1. Menyusun modul tentang penyusunan Laporan keuangan yang sederhana untuk UMKM yang sesuai dengan SAK EMKM.

2. Tim Pengabdian memperkenalkan diri dan menjelaskan maksud kedatangan di tempat usaha pelaku UMKM dengan memperlihatkan surat tugas pengabdian dari kampus .

3. Tim membagikan modul sosialisasi kepada pelaku UMKM

4. Tim memberikan penjelasan tentang penyusunan laporan keuangan yang sesuai dengan SAK EMKM dengan panduan modul pelatihan yang telah dibagikan

5. Untuk mengevaluasi kemampuan para peserta tentang pelatihan ini, para peserta diberikan kesempatan untuk bertanya dan diskusi, dan diberikan soal kasus untuk menyusun laporan keuangan.

6. Memberikan sertifkat kepada peserta sebagai apresiasi untuk pengelola UMKM di Kabupaten Kampar yang telah mendapat pelatihan penyusunan laporan keuangan yang telah dilakukan TIM.

Kegiatan Pelatihan dilakukan pada bulan agustus dan september 2020, yang dimulai pukul 08.00 wibselesai. Setelah dilakukan pelatihan diharapkan UMKM sudah bisa menyusun laporan keuangan. Tim memberikan beberapa contoh latihan kasus dalam penyusunan laporan keuangan, dan menyarankan pengelola UMKM untuk menyusun laporan keuangan nya. Pengelola UMKM bisa membuat laporan keuangan yang tepat seperti laporan laba rugi, laporan perubahan modal, dan neraca adalah merupakan keberhasilan dari pelatihan ini.

\section{HASIL DAN PEMBAHASAN}

Kegiatan memberikan pelatihan penyusunan laporan keuangan UMKM di Kabupaten Kampar dengan peserta terdiri dari pengelola UMKM di Kabupaten Kampar. Adapun materi pada kegiatan peningkatan pelatihan penyusunan laporan keuangan UMKM di Kabupaten Kampar antaralain aturan terkait dengan penyusunan laporan keuangan UMKM, jenis-jenis laporan keuangan yang harus disiapkan oleh pengelola UMKM dan cara penyusunan laporan keuangan UMKM yang seharusnya kepada pengelola UMKM berdasarkan SAK EMKM. Dalam pelaksanaan kegiatan ini, tim akan mengajarkan akun- akun laporan keuangan yang dapat dijadikan dasar dalam penyusunan laporan keuangan UMKM sehingga pengelola UMKM tepat dalam melakukan penyusunan laporan keuanagn UMKM. Hal ini juga akan berpengaruh terhadap laporan keuangan UMKM yang dihasilkan, antara lain laporan Laba Rugi, Laporan perubahan modal dan Neraca. Diharapkan dengan peningkatan pemahaman pengelola UMKM terhadap penyusunan laporan keuangan UMKM ini, akan menghasilkan Laporan Keuangan sesuai dengan Standar akuntansi untuk EMKM yang berlaku. Hal ini akan sangat berguna bagi pengelola UMKM dalam mengelola UMKM.

Dalam pelaksanaan Kegiatan ini dilakukan dengan mendatangi pengelola UMKM yang berada di Kabupaten Kampar. Pertama-tama tim pengabdian melakukan kunjungan dan survey ke PLUT KUMKM Kabupaten Kampar pada bulan agustus 2020 untuk mendapatkan informasi awal tentang UMKM yang akan menjadi sasaran kegiatan pengabdian. Berhubung tahun 2020 terjadi pandemi covid19 maka tidak memungkinkan untuk melakukan pelatihan dengan cara mengumpulkan pengelola UMKM di satu ruangan, sehingga berdasarkan kesepakatan tim pengabdian dengan pihak terkait maka kegiatan pengabdian tentang pelatihan penyusunan laporan keuangan UMKM ini akan dilakukan dengan cara mendatangi beberapa UMKM terpilih. Berdasarkan kesepakatan tersebut, maka pada tanggal 12 September 2020, tim melakukan kunjungan ke UMKM yang terpilih sebagai kelompok sasaran pengabdian untuk melakukan pelatihan kepada pengelola UMKM tentang cara menyusun laporan keuangan yang sesuai dengan standard EMKM yang berlaku di Indonesia. Laporan keuangan yang akan dilatih adalah penyusunan laporan laba rugi, Laporan perubahan modal dan Neraca. 

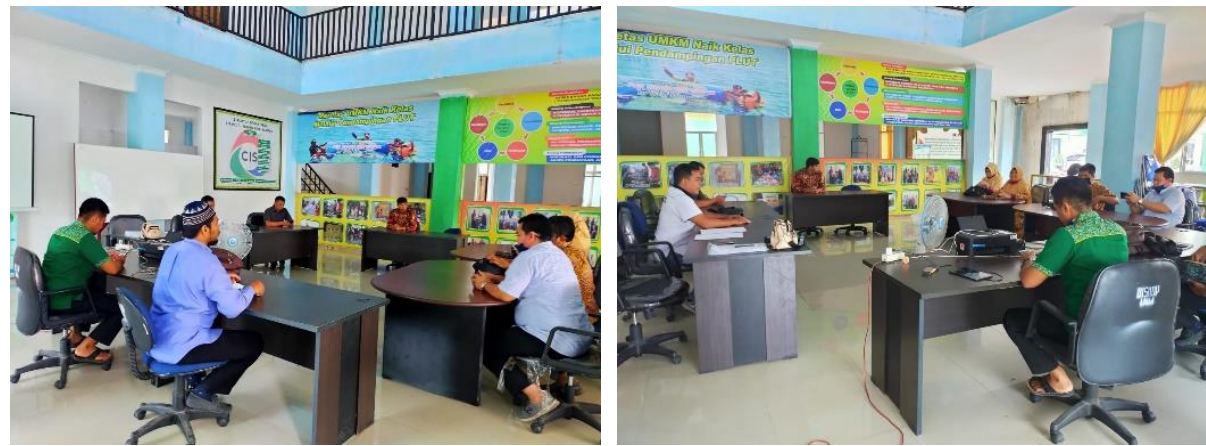

Gambar 1. Survey dan pembahasan tentang pelaksanaan kegiatan pengabdian

Pertama-tama dilakukan perkenalan antara tim dan pengelola dan menyampaikan maksud kedatangan tim serta menunjukkan surat penugasan dari pimpinan kampus kepada pengelola UMKM dengan tetap melaksanakan protocol covid19. Selanjutnya melakukan wawancara ke pengelola UMKM yang dikunjungi untuk mengetahui kemampuan pengelola UMKM tentang penyusunan laporan keuangan. Kemudian Tim melakukan pengecekan terhadap cara penyusunan laporan keuangan yang telah mereka buat selama ini. Selanjutnya tim akan membantu mengajarkan cara penyusuanan laporan keuangan UMKM sesuai SAK EMKM yang lebih tepat disertai dengan contoh kasus dengan menggunakan panduan modul yang telah disiapkan oleh tim. Sepanjang kegiatan ini peserta bisa langsung mendiskusikan dengan tim hal- hal yang berkaitan dengan penyusunan laporan keuangan UMKM sampai mereka memahaminya.
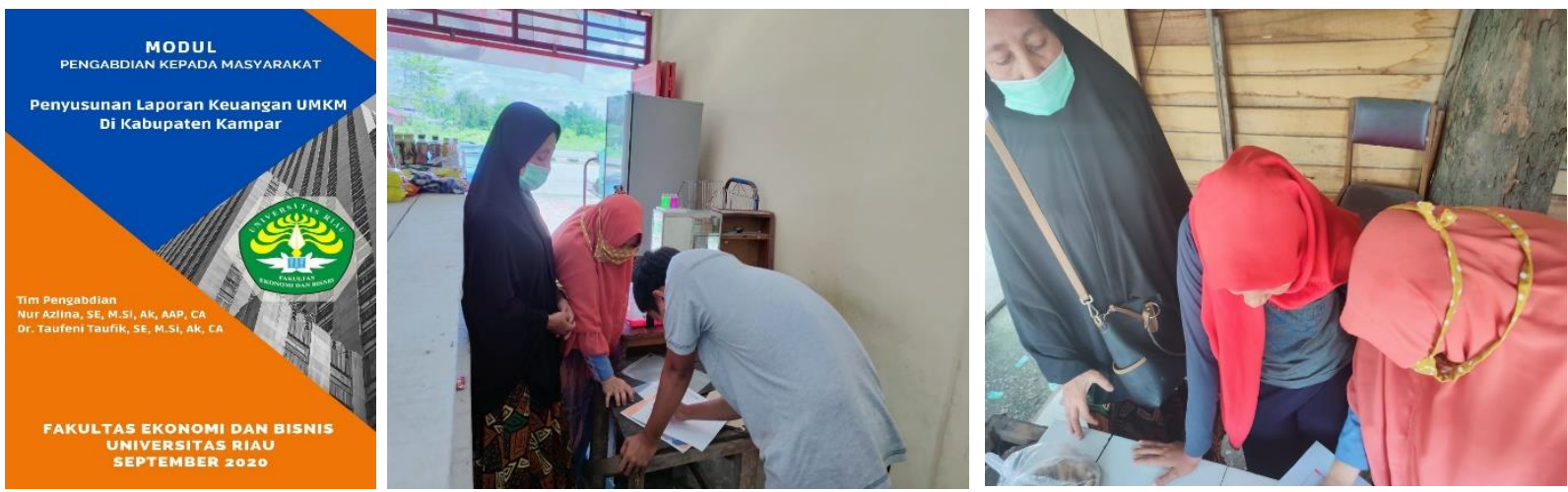

Gambar 2. Modul dan pelaksanan Pelatihan penyusunan laporan keuangan UMKM

Pemahaman akuntansi akan memberikan manfaat bagi mereka dalam hal pengelolaan keuangan UMKM. Pelatihan penyusunan laporan keuangan yang berdasarkan pada keadaan yang sebenarnya di dalam bisnis UMKM dan penggunaan pendekatan yang tepat akan menjadikan pengelola UMKM memahami akuntansi secara mudah dan cepat. Pemahaman terhadap akuntansi diharapkan akan membantu pengelola UMKM untuk mengelola sumber dana dan penggunaan secara cermat dan efisien sehingga UMKM dapat berkembang lebih baik dan dapat meningkatkan kinerja UMKM.

Luaran dari pelaksanaan pelatihan ini adalah pengelola UMKM memahami akuntansi dan dapat menyusun laporan keuangan yang sesuai dengan SAK EMKM sehingga pengelola UMKM dapat membuat laporan keuangan yang sesuai standar EMKM. Dalam proses penyusunan laporan keuangan ini, pengelola UMKM mendapatkan panduan dari modul yang telah disediakan Tim. Untuk mengevaluasi kemampuan para peserta tentang pelatihan ini, para peserta diberikan kesempatan untuk bertanya dan diskusi dan mengerjakan latihan kasus yang disediakan di modul. Efektivitas pelatihan dapat dilihat dari proses kegiatan yang telah dilakukan tersebut, dalam hal ini baik para peserta maupun pelaksana kegiatan cukup antusias mengikuti acara tersebut sampai selesai. Bagi pengelola UMKM yang sudah mendapatkan pelatihan diberikan sertifikat sebagai apresiasi terhadap partisipasi mereka mengikuti pelatihan ini. Setelah kegiatan pelatihan ini selesai, tim diundang oleh Kepala Dinas Perdagangan, Koperasi dan UMK Kabupaten Kampar untuk melakukan diskusi membahas tentang pendampingan pemberdayaan UMKM di Kabupaten Kampar sebagai upaya keberlanjutan dari kegiatan ini. 


\section{KESIMPULAN}

Apresiasi serta partisipasi yang diberikan oleh pengelola UMKM Kabupaten Kampar sangat bagus mengingat sebelumnya pengetahuan mereka tentang akuntansi dan penyusunan laporan keuangan UMKM sesuai SAK EMKM sangat minim. Dan setelah dilakukan pelatihan ini, pengelola UMKM memahami akuntansi, mendapatkan informasi dan materi tentang bentuk laporan keuangan yang sesuai dengan SAK EMKM Indonesia serta proses penyusunan laporan keuangan yang sesuai dengan SAK EMKM. Dengan keahlian ini diharapkan para pengelola UMKM bisa menyusun laporan keuangan untuk usahanya. Laporan ini bisa digunakan untuk menganalisa keuangan UMKM dan pertumbuhan usaha mereka. Laporan ini juga bisa digunakan sebagai salah satu persyaratan ketika inigin mengajukan pinjaman dana sebagai salah satu cara dalam pengembangan usaha UMKM.

Dalam pelaksanaan pelatihan ini ditemukan beberapa kendala yaitu beberapa pengelola UMKM yang ditemui tingkat pendidikan formal masih sangat minim sehingga dbutuhkan waktu yang agak panjang untuk memberikan penjelasan, dan masih ditemui pengelola UMKM yang masih belum memahami menggunakan aplikasi handphone android tuk berkomunikasi lebih lanjut. Dan karena TIM harus mendatangi satu persatu maka hanya beberapa UMKM yang mendapatkan pelatihan. Untuk kegiatan pelatihan selanjutnya sebaiknya bisa mengumpulkan lebih ramai pelaku UMKM disatu tempat sehingga waktu pelatihan bisa lebih lama dan peserta yang mendapatkan pelatihan bisa lebih ramai.

\section{UCAPAN TERIMA KASIH}

Penulis mengucapkan terima kasih kepada dekan Fakultas Ekonomi dan Bisnis Universitas Riau yang telah memberi dukungan keuangan terhadap pengabdian ini, Kepala Dinas Perdagangan, Koperasi dan UMK Kabupaten Kampar atas partisipasinya.

\section{DAFTAR PUSTAKA}

Amani, Tatik. 2018. Penerapan SAK-EMKM Sebagai Dasar Penyusunan Laporan Keuangan UM, (Studi Kasus di UD Dua Putri Solehah Probolinggo). Jurnal ASSET: Jurnal Ilmiah Ilmu Akuntansi, Keuangan dan Pajak, 2(2).

Agustina, Y., Setianingsih, S., \& Santoso, Y. D. 2019. Pelatihan Penyusunan Laporan Keuangan Bagi Entitas Mikro, Kecil, dan Menengah Bidang Usaha Dagang pada UMKM Binaan Pusat Inkubasi Bisnis Syariah Majelis Ulama Indonesia. Intervensi Komunitas: Jurnal Pengabdian Masyarakat, 1(1), 1-13.

Dharma, A. B., TDKW, Y., \& Masturi, D. N. 2019. Pelatihan dan Penyusunan Laporan Keuangan dan Pajak Pelaku UMKM Produk Sampah di Desa Polanharjo Klaten. Wasana Nyata: Jurnal Pengabdian kepada Masyarakat, 3(2), 144-149.

Ikatan Akuntan Indonesia. 2016. SAK EMKM. Jakarta: Salemba Empat.

Kieso, Donald. E, dkk. 2018. Akuntansi Intermediate. Jakarta : Erlangga.

Kurniawati, Elisabeth Penti, Paskah Ika Nugroho Dan Chandra Arifin. 2012. Penerapan Akuntansi Pada Usaha Mikro Kecil Dan Menengah (UMKM). JMK, 10(2).

Machfuzhoh, A., Lutfi, \& Utami, I. 2020. Pelatihan Pembukuan Sederhana Bagi UMKM Menuju UMKM Naik Kelas di Kecamatan Grogol. Jurnal Pengabdian dan Peningkatan Mutu Masyarakat, 1(2), 109-116.

Mulyaga, Fian. 2016. Faktor-Faktor Yang Mempengaruhi Implementasi Standar Akuntansi Keuangan Entitas Tanpa Akuntabilitas Publik Pada UMKM.

Prajanto, Agung dan Septriana, Ira. 2018. Implementasi Penerapan SAK EMKM serta Dampaknya pada Kualitas Pelaporan Keuangan UMKM, Studi Kasus Pada UMKM Se Kota Semarang. Jurnal Aset, 20(2).

Prasetyo, Aries Heru. 2010. Sukses Mengelola Keuangan Usaha Mikro: Kecil Menengah. Jakarta: PT. Elex Media Komputindo

Pujiyanti, Ferra. 2015. Laporan Keuangan Khusus Untuk Pajak \& UKM. Jakarta: Lembar Pustaka Indonesia

Pustapa, P., Riandra, A., \& Aisyah, R. 2019. Pelatihan Akuntansi Keuangan Bagi UMKM Kota Madya Medan. Jurnal Pengabdian Kepada Masyarakat (JPM), 1(1), 8-12.

Soraya, Rynandi, O., Zawitri, S., Yuliana, E. S., Kartikawati, T. S., Rezano, T., et al. 2018. Pelatihan Penyusunan Laporan Keuangan Berdasarkan SAK ETAP Bagi UMKM di Kecamatan Sungai Pinyuh. Jurnal Pengabdian kepada Masyarakat, 2(1). 
Syahrenny, Nenny. 2019. Pelatihan Penyusunan Laporan Keuangan UMKM Sesuai SAK EMKM. Prosiding Seminar Nasional Penelitian Dan Pengabdian Masyarakat Ke-2, Online ISSN 2655-978, LP4MP, Mojokerto, 17 Desember 2019.

Yuniarta, Gede Adi. 2013. Persepsi Praktisi Akuntans Terhadap Kelayakan Hasil Pengembangan Perangkat Simulasi Akuntansi untuk Usaha Kecil Menengah Berbasis Multimedia. Vol.3, No.1. Universitas Pendidikan Ganesha. 